\title{
Follicular Population and Oestrogen Receptor Alpha in Ovary of the Bitch
}

\author{
R. DOLEŽEL ${ }^{1}$, R. KYLIÁNKOVÁ ${ }^{1}$, V. KUMMER ${ }^{2}$, J. MAŠKOVÁ 2 \\ P. STARÁ ${ }^{1}$, R. VITÁSEK ${ }^{1}$ \\ ${ }^{1}$ University of Veterinary and Pharmaceutical Sciences, Brno, Czech Republic; ${ }^{2}$ Veterinary Research Institute,
} Brno, Czech Republic

Received October 27, 2003

Accepted February 11, 2004

Abstract

Doležel R., R. Kyliánková, V. Kummer, J. Mašková, P. Stará, R. Vitásek: Follicular Population and Oestrogen Receptor Alpha in Ovary of the Bitch. Acta Vet. Brno 2004, 73: $37-43$.

The objective of this study was to evaluate the follicular population on ovaries as related to the phases of oestrous cycle and age in bitches. Several characteristics of follicular population on ovaries in follicular (Group 1, $\mathrm{n}=3$ ), luteal (Group 2, $\mathrm{n}=7$ ) and anoestral (Group 3, $\mathrm{n}=8$ ) phases of the oestrous cycle and in young $(\leq 6$ years, $n=12)$ and old $(\geq 7$ years, $n=6)$ bitches were observed. The numbers and proportions of primary, secondary, tertiary and atretic follicles, diameters of the follicles and oocytes and distribution of oestrogen receptor alpha in ovaries after ovariectomy were evaluated. Microscopical examination of slices stained with haematoxylin-eosin was performed in $50 \mathrm{~mm}^{2}$ of ovarian tissue in each animal and immunohistochemical detection of oestrogen receptor alpha was performed using a monoclonal oestrogen receptor alpha antibody. Average numbers of all follicles were found 567 (31\% atretic), 449 (27\% atretic) and 408 (37\% atretic) in the Group 1, 2 and 3, respectively. Proportions of primary, secondary and tertiary follicles regardless of phase of the oestrous cycle as well as age of animals were $72.0 \%, 24.5 \%$ and $3.5 \%$, respectively. Proportions of these follicles in various phases of the oestrous cycle as well as in young and old animals were not different. Diameters of primary $(40.2 \pm 15.20 \mu \mathrm{m})$, secondary $(102.4 \pm 36.60 \mu \mathrm{m})$ and tertiary $(323.7 \pm 95.84 \mu \mathrm{m})$ follicles as well as diameters of oocytes in secondary $(80.7 \pm 16.66 \mu \mathrm{m})$ and tertiary $(105.8 \pm 17.64 \mu \mathrm{m})$ follicles increased synchronously to follicular development $(p<0.01)$. High intensity of nuclear oestrogen receptor alpha immunostaining was found within surface epithelium, in primary follicles and in luteal cells. Medium immunoreaction was seen in secondary follicles and low expression of oestrogen receptor alpha was in tertiary follicles. No immunoreaction of oestrogen receptor alpha was found in atretic follicles. The results show similar characteristics of follicular population in various phases of the oestrous cycle both in young and old bitches. Diameters of follicles as well as diameters of oocytes increased and contrary to this oestrogen receptor alpha expression decreased synchronously to follicle development. The study did not show an effect of oestrous cycle and age on proportions of primary, secondary, tertiary and atretic follicles as well as oestrogen receptor alpha distribution on ovaries of the bitch.

Follicle, atretic follicle, oestrogen receptor alpha, oestrous cycle, age, bitch

The morphological and functional properties of ovarian follicles represent objective of the recent research in many species of animals because quantity and quality parameters of the follicular population define potency in reproduction. In addition, deeper knowledge of follicular development gives an opportunity to increase efficiency of biotechnological methods in reproduction. However, there is a lack of data about follicular population in bitches.

Ovaries in newborn mammals contain several tens or hundreds of thousands of primordial follicles, which represent a pool from which they will be recruited for growth during postnatal life (Baker 1972). About half a million of primordial and primary follicles are present on ovaries of a newborn puppy. Ovarian follicles successively develop and are

Address for correspondence:

Doc. MVDr. Radovan Doležel, CSc.

Clinic of Ruminant Diseases

University of Veterinary and Pharmaceutical Sciences

Palackého 1-3,612 42 Brno, Czech Republic

Phone:+ 420541562316

Fax: + 420541562332

E-mail:dolezelr@vfu.cz 
destroyed during postnatal life and the total number of follicles declines to 35000 and 500 in the middle and by the end of reproduction activity in bitches. The number of follicles is higher in crossbreeds and there is a positive correlation of total number of follicles with size of the ovary as well as size of the bitch (Durrant et al. 1998).

Distribution of ovarian steroid receptors represents qualitative parameter of the ovarian structures because steroid hormones regulate ovarian functions via endocrine, paracrine and autocrine mechanisms (Pineda 2003). In spite of the fact that oestrogen and progesterone receptors have been detected in ovaries of several animal species, only progesterone receptors have been described in canine ovaries (Vermeirsch et al. 2001).

Object of this study was the occurrence of ovarian follicles in various developmental stages in young and old bitches as well as in various phases of oestrous cycle, diameters of the follicles and oocytes and distribution of oestrogen receptor alpha in canine ovaries.

\section{Materials and Methods}

Experimental animals and samples

Eighteen bitches of various breeds between 9 months and 11 years of age, presented for ovariectomy, were used in the study. Stages of oestrous cycle were determined on the basis of anamnesis, clinical examination, vaginal cytology and blood progesterone analysis performed before ovariectomy. Three experimental groups were established according to the phase of oestrous cycle - Group 1 (follicular phase - pro-oestrus and oestrus, $\mathrm{n}=3$ ), Group 2 (luteal phase - dioestrus, $\mathrm{n}=7$ ) and Group 3 (anoestral phase - anoestrus, $\mathrm{n}=8$ ). In addition the bitches were divided by age - young $(\leq 6$ years, $n=12)$ and old $(\geq 7$ years, $n=6)$. Thirty six ovaries were visually evaluated immediately after ovariectomy and they were fixed in $10 \%$ neutral buffered formalin until laboratory examination.

Laboratory examination

Six slices from each ovary were paraffin-embedded and then sections were made and stained with haematoxylin and eosin for histological examination. Immunohistochemical detection of oestrogen receptor alpha $(\mathrm{ER} \alpha)$, carried out in paraffin sections, was preceded by heat-induced antigen retrieval in a pressure cooker. The prediluted monoclonal anti-ER $\alpha$ antibody $1 \mathrm{D} 5$ and the visualization system EnVision ${ }^{\mathrm{TM}_{+}}$(Dako, USA) with 3,3' diaminobenzidine (Fluka Chemie, Germany) as the chromogen were used in accordance with instructions of the manufacturers.

Small oocyte enclosed by a single layer of cuboidal follicular cells, oocyte with several layers of follicular cells (as case may be vesicles among follicular cells), and oocyte in distinct uniform cavity surrounded by multiple layers of differentiated follicular cells were classified as primary, secondary and tertiary follicles, respectively. Irregularity and reduction of layers of the follicular cells and symptoms of cell degeneration were considered as symptoms of follicle atresia. Numbers of non-atretic as well as atretic primary, secondary and tertiary follicles were determined in 20 visual areas (total area $=50 \mathrm{~mm}^{2}$ ) in each animal. Follicle diameters were measured in 200 follicles of each developmental stage and oocyte diameters were measured in 100 oocytes in secondary as well as tertiary follicles. Follicle and oocyte diameters and intensity of ER $\alpha$ immunostaining were determined by computer image analysis using the Lucia G system (Laboratory Imaging, Czech Republic).

Statistical evaluation

T-test for Paired Comparison was used for evaluation of follicular population in various phases of the oestrous cycle as well as for diameters of follicles and oocytes. Follicular populations in young and old bitches were compared by means of Chi-Square Test or Fisher's Exact Test.

\section{Results}

Total number of ovarian follicles found in $50 \mathrm{~mm}^{2}$ of ovarian tissue was $567(31 \%$ atretic), 449 (27\% atretic) and 408 (37\% atretic) in Groups 1, 2 and 3, respectively. A higher total number of follicles and a lower rate of atresia were found in young bitches compared to the older ones (1321:999, $\mathrm{p}<0.01$ and $36 \%: 51 \%, \mathrm{p}<0.001)$. Proportions of primary, secondary, tertiary follicles regardless of the phase of oestrous cycle as well as age of animals were $72.0 \%, 24.5 \%$ and $3.5 \%$, respectively. Proportions of these 
follicles in various phases of the oestrous cycle as well as in young and old animals were similar (Fig. 1, 2).

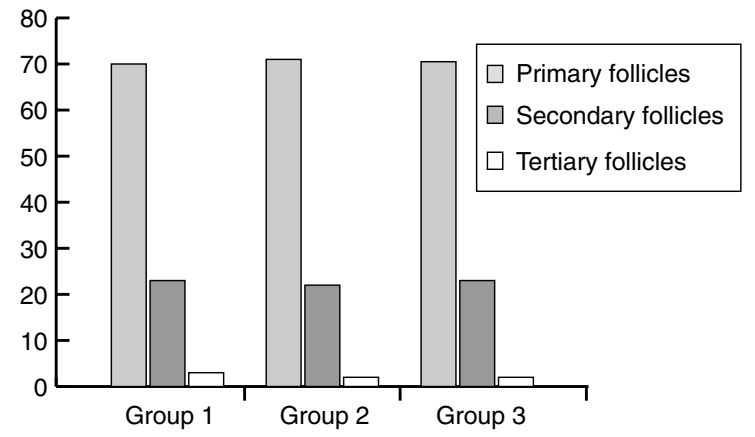

Fig.1. Proportions of primary, secondary and tertiary follicles in $50 \mathrm{~mm}^{2}$ of ovarian tissue in bitches in follicular (Group 1, n =3), luteal (Group 2, n =7) and anoestral (Group 3, n = 8) phases of the oestrous cycle (\%).

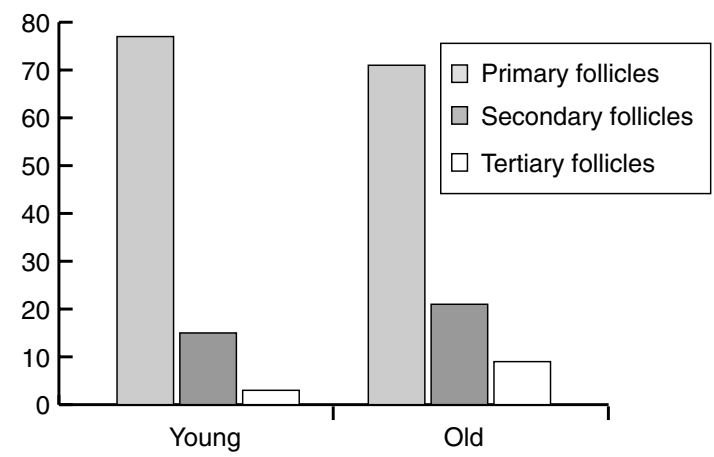

Fig. 2. Primary, secondary and tertiary follicles in $50 \mathrm{~mm}^{2}$ of ovarian tissue in young ( $(\leq 6$ years) and old ( $\geq 7$ years) bitches $(\%)$.

Diameters of follicles increased synchronously to follicle development (Table 1) and diameters of oocytes in tertiary follicles were higher in comparison with oocytes in secondary follicles (Table 2).

High and moderate intensities of nuclear ER $\alpha$ immunostaining were determined in surface epithelium as well as in follicular cells of primary and smaller secondary follicles in all groups (Plate V, Fig. 3). The same intensity was found in luteal cells of corpora lutea in Group 2 (Plate V, Fig 4). ER $\alpha$ was expressed at low level in granulosa cells of tertiary follicles. No positive ER $\alpha$ immunostaining was observed in atretic follicles.

Table 1

Diameters of primary, secondary and tertiary follicles in ovaries of bitches

\begin{tabular}{|l|c|c|c|}
\hline \multirow{2}{*}{ Follicles } & \multirow{2}{*}{$\mathrm{n}$} & Mean \pm S.D. & Diameters $[\mathrm{mm}]$ \\
\cline { 3 - 4 } & & $\mathrm{n}$ & $16.03-93.19$ \\
\hline Primary & 200 & $40.2 \pm 15.2^{\mathrm{a}}$ & $48.56-234.95$ \\
\hline Secondary & 200 & $102.4 \pm 36.6^{\mathrm{b}}$ & $73.67-551.74$ \\
\hline Tertiary & 200 & $323.7 \pm 95.8^{\mathrm{c}}$ & \\
\hline
\end{tabular}

$\mathrm{a}, \mathrm{b}, \mathrm{c}-p<0.01$ 
Table 2

Diameters of oocytes in secondary and tertiary ovarian follicles in bitches

\begin{tabular}{|c|c|c|c|}
\hline \multirow[b]{2}{*}{ Follicles } & \multirow[b]{2}{*}{$\mathrm{n}$} & \multicolumn{2}{|c|}{ Diameters of oocytes [mm] } \\
\hline & & Mean \pm S.D. & Min - Max \\
\hline Secondary & 100 & $80.71 \pm 16.66^{\mathrm{a}}$ & $48.59-118.54$ \\
\hline Tertiary & 100 & $105.8 \pm 17.64^{\mathrm{b}}$ & $67.39-145.35$ \\
\hline
\end{tabular}

$\mathrm{a}, \mathrm{b}-p<0.01$

\section{Discussion}

Primordial follicles in canine ovaries with a diameter of $25 \mu \mathrm{m}$ which were characterized by single layer of follicle cells (Durrant et al. 1998) are comparable to primary follicles with diameter $40.2 \pm 15.2 \mu \mathrm{m}$ in our study. Preantral and advanced preantral follicles (diameter $78 \pm 15$ and $211.4 \pm 1.5 \mu \mathrm{m}$ ) in that study would be compared with small and large secondary follicles but we evaluated only one group of secondary follicles with diameter $102.4 \pm 36.6 \mu \mathrm{m}$. Early antral follicles with diameter $360.5 \pm 18.8$ $\mu \mathrm{m}$ corresponded to tertiary follicles in our study (diameter $323.7 \pm 95.8 \mu \mathrm{m}$ ). Durrant et al. (1998) describe advanced preantral follicles as a unique group of canine follicles characterized by fully grown, lipid-filled oocyte within a preantral-like granulosa complex. The acquisition of dense cytoplasmic lipid during growth of canine oocytes has been described by Tesoriero (1982).

Advanced preantral follicles with diameters of about $210 \mu \mathrm{m}$ which contain oocytes $115 \mu \mathrm{m}$ in diameter (Bola mba et al. 2002) as antral follicles (Hewitt et al. 1998; Hewitt and England 1999; Otoi et al. 2000b) were used for in vitro maturation (IVM) of bitch oocytes. IVM of oocytes represents an important and complicated stage of in vitro production of embryos especially in bitches, because in contrast to the majority of mammalian species canine oocytes reach metaphase II as far as oviduct within 2-5 days after ovulation (Andersen and Simpson 1973; Concannon et al. 1989; Tsuitsui 1989). Hewitt and England (1997) and Otoi et al. (2000a) demonstrated that more oocytes progressed to metaphase II stage if their sizes were > $100 \mu \mathrm{m}$ in diameter and donor bitches were 1-6-yearold. Thus diameters of follicles as well as oocytes were useful in selection of suitable follicles for isolation and IVM of oocytes. With respect to the method of follicle evaluation in our study, larger secondary follicles and tertiary follicles are suitable for IVM of oocytes in bitches.

Experimental bitches were devided in two groups by their ages: $\leq 6$ years (young bitches) and $\geq 7$ years (old bitches) because generally reproductive efficiency decreases after the 7 th year of age in bitches. In accordance with this data, the total number of follicles in $50 \mathrm{~mm}^{2}$ of ovarian tissue was lower and the percentage of atretic follicles was higher in old bitches compared to young ones in our study (999: 1321 and 51\%:36\%). Likewise Durrant et al. (1998) isolated more follicles per gram of ovarian tissue in youngest bitches - donors compared to older ones. In addition the ovaries of bitches 6 month of age or younger yielded a lower percentage of follicles in advanced stage of development but more atretic follicles than other age groups in that study. High rate of follicle atresia in prepubertal bitches can illustrate an acceleration of atresia during the first few moths after birth in a bitch (Andersen and Simpson 1973). We could not evaluate follicular population a short time after birth because prepubertal bitches were not included in the study.

Two types of follicle atresia in bitches were described by Spanel-Borowski (1981). Degenerative changes of oocytes are typical for the first type and a degeneration of granulosa layer is typical for the second type of atresia. The first type predominates in preantral follicles, whereas the second type is typical for antral follicles. Above all, the changes in granulosa complex were used for evaluation of follicle atresia in our study. 
In spite of similar proportions of primary, secondary and tertiary follicles in various phases of oestrous cycle in our study Durrant et al. (1998) found significant differencies in proportions of isolated follicles in relation to ovary status. They isolated more primary and early secondary follicles in pro-oestrus and metoestrus compared to oestrus, as well as more tertiary follicles in oestrus compared to pro-oestrus. But ovary status did not affect the total number of follicles per gram of ovary in postpubertal bitches.

In spite of that, progesterone and oestrogen receptors have been detected in ovaries of several animal species (Kim and Greenwald 1987ab; Vesanen et al. 1991; Vesanen 1993; Od ore et al. 1999) as well as in human ovaries (I w a i et al. 1990) data about oestrogen receptor in canine ovaries are missing. Vermeirsch et al. (2001) described progesterone receptor in various structures of canine ovary. They described an increase in staining intensity for progesterone receptor in follicles synchronously with follicle development. Contrary to this, the staining intensity for oestrogen alpha receptor decreased synchronously with follicle development in this study. No differences in receptor distribution and staining intensity in relation to oestrous cycle, except for corpus luteum and theca externa of tertiary follicles, were found in that study. In accordance with these results, distribution and expression of oestrogen receptor alpha were similar during the various phases of oestrous cycle in our study. Thus concentration of steroid hormones in peripheral blood probably does not infuence oestrogen receptor alpha on canine ovaries. Likewise, Vermeirsch et al. (2001) found little correlation between expression of progesterone receptor in ovary and oestradiol, progesterone or testosterone concentrations in peripheral blood. Probably there is different regulating mechanism for steroid hormone receptors in ovarian structures compared with other sexual organs. It seems that the stage of development is more important for expression of hormone receptors in the follicles than blood concentrations of the corresponding hormones.

The results of our study show similar proportions of primary, secondary, tertiary and atretic follicles in young as well as old postpubertal bitches and similar distribution of oestrogen receptor alpha in canine ovaries in follicular, luteal and anoestral phases of the oestrous cycle. Diameters of follicles as well as diameters of oocytes increase and, on the contrary, oestrogen receptor alpha expression decreases synchronously to follicle development.

\section{Folikulární populace a estrogenový receptor alfa na vaječnících fen}

Předmětem studie bylo hodnocení folikulární populace na vaječnících ve vztahu $\mathrm{k}$ fázím pohlavního cyklu a věku u fen. $\mathrm{V}$ práci byly sledovány některé vlastnosti folikulární populace na vaječnících fen ve folikulární (Skupina $1, n=3$ ), luteální (Skupina $2, \mathrm{n}=7$ ) a anestrální (Skupina 3, n = 8) fázi ř́jového cyklu a u fen mladých ( $\leq 6$ let, $\mathrm{n}=12$ ) a starých $(\geq 7$ let, $n=6)$. Hodnotily se počty a procentuální podíly primárních, sekundárních, terciárních a atretických folikulů, dále průměry folikulů a oocytů a distribuce estrogenového receptoru alfa na vaječnících získaných po ovariektomii. Mikroskopické vyšetření řezů obarvených hematoxylin-eosinem bylo provedeno na $50 \mathrm{~mm}^{2}$ ovariální tkáně (20 zorných polí). Pro immunohistochemický průkaz estrogenového receptoru alfa bylo použito monoklonální protilátky na estrogenový receptor alfa $1 \mathrm{D} 5$. Celkové počty folikulů ve skupinách 1, 2 a 3 byly 567 (31\% atretických), 449 (27\% atretických) a 408 (37\% atretických). Procentuální podíly primárních, sekundárních a terciárních folikulů, nehledě na fázi pohlavního cyklu tvořily $72,0 \%, 24,5 \%$ a 3,5 \%. Poměry těchto folikulů v jednotlivých fázích ř́íjového cyklu, tak jako u mladých a starých fen, byly obdobné. Průměry primárních $(40,2 \pm 15,20 \mu \mathrm{m})$, sekundárních $(102,4 \pm 36,60 \mu \mathrm{m})$ a terciárních $(323,7 \pm 95,84$ $\mu \mathrm{m})$ folikulů, obdobně jako průměry oocytů v sekundárních $(80,7 \pm 16,66 \mu \mathrm{m})$ a terciárních 
$(105,8 \pm 17,64 \mu \mathrm{m})$ folikulech se zvyšovaly současně $\mathrm{s}$ folikulárním vývojem $(\mathrm{p}<0,01)$. Vysoká imunoreaktivita pro estrogenový receptor alfa byla zjištěna $v$ povrchovém epitelu, v primárních folikulech a v luteálních buňkách žlutých tělísek. Střední reakce byla zaznamenána v sekundárních folikulech a nízká v terciárních folikulech. Imunoreaktivita pro estrogenový receptor alfa nebyla zjištěna $\mathrm{v}$ atretických folikulech. Výsledky ukazují obdobné vlastnosti folikulární populace, jak $\mathrm{v}$ různých fázích pohlavního cyklu, tak u mladých i starých fen. Rozměry folikulů i oocytů se zvyšují a naopak reakce estrogenového receptoru alfa se snižuje současně s postupujícím folikulárním vývojem. Studie neukázala žádný vliv pohlavního cyklu a věku na zastoupení primárních, sekundárních, terciárních a atretických folikulů ani na distribuci estrogenových receptorů alfa na ováriích fen.

\section{Acknowledgements}

Authors thank MVDr. Mirko Vyskočil for statistical evaluation. The study was supported by MŠMT of the Czech Republic grant No. 161700002, and MZe Czech Republic project No. M03-99-01.

\section{References}

ANDERSEN, AC, SIMPSON, ME 1973: In: The Ovary and Reproductive Cycle of the Dog (Beagle) Los Altos, CA: Geron-X Inc: 72

BAKER, T 1972: Oogenesis and ovarian development. In: Balin H, Glasser S, (eds), Reproductive Biology. Amsterdam: Excerpta Medica, p. 398-447

BOLAMBA, D, RUSS, KD, OLSON, MA, SANDLER, JL, DURRANT, BS 2002: In vitro maturation of bitch oocytes from advanced preantral follicles in synthetic oviduct fluid medium: serum is not essential. Theriogenology 58: 1689-1703

CONCANNON, PW, McCANN, JP, TEMPLE, M 1989: Biology and endocrinology of ovulation, pregnancy and parturition in the dog. J Reprod Fertil, Suppl 39: 3-25

DURRANT, BS, PRATT, NC, RUSS, KD, BOLAMBA, D 1998: Isolation and characterization of canine advanced preantral and early antral follicles. Theriogenology 49: 917-932

HEWITT, DA, ENGLAND, GCW 1997: Effect of preovulatory endocrine events upon maturation of oocytes of domestic bitches. J Reprod Fertil, Suppl 51: 83-91

HEWITT, DA, ENGLAND, GCW 1999: Synthetic oviductal fluid and oviductal cell coculture for canine oocyte maturation in vitro. Anim Reprod Sci 55: 63-75

HEWITT, DA, WATSON, PF, ENGLAND, GCW 1998: Nuclear staining and culture requirements for in vitro maturation of domestic bitch oocytes. Theriogenology 49: 1083-1101

IWAI, T, NANBU, Y, IWAI, M, TAII, S, FUJII, S, MORI, T 1990: Immunohistochemical localization of oestrogen receptors and progesterone receptors in the human ovary throughout the menstrual cycle. Virchows Archiv A 417: $369-375$

KIM, I, GREENWALD, GS 1987a: Effects of estrogens on follicular development and ovarian and uterine estrogen receptors in the immature rabbit, guinea-pig and mouse. Endocrinol Japon 34: 871-878

KIM, I, GREENWALD, GS 1987b: Estrogen receptors in ovary and uterus of immature hamster and rat: effects of estrogen. Endocrinol Japon 34: 45-53

ODORE, R, RE, G, BADINO, P, DONN, A, VIGO, D, BIOLATTI, B, GIRARDI, C 1999: Modulations of receptor concentrations for adrenaline, steroid hormones, prostaglandin F2+ and gonadotropins in hypophysis and ovary of dairy cows with ovarian cysts. Pharmacol Res 39: 297-304

OTOI, T, FUJII, M, TANAKA, M, SUZUKI, T 2000a: Canine oocyte diameter in relation to meiotic competence and sperm penetration. Theriogenology 54: 535-542

OTOI, T, MURAKAMI, M, FUJII, M, TANAKA, M, OOKA, A, UNE, S 2000b: Development of canine oocytes matured and fertilized in vitro. Vet Res 146: 52-53

PINEDA, MH 2003: Female Reproductive System. In: Pineda MH, Doplet MP: McDonalds Veterinary Endocrinology and Reproduction (5th ed). Iowa State Press, pp 283-340

SPANEL-BOROWSKI, K 1981: Morphological investigations on follicular atresia in canine ovaries. Cell Tiss Res 214: $158-168$

TESORIERO, JV 1982: A morphologic, cytochemical, and chromatographic analysis of lipid yolk formation in the oocytes of the dog. Gamete Res 6: 267-279

TSUITSUI, T 1989: Gamete physiology and timing of ovulation and fertilization in the dog. J Reprod Fertil Suppl 39: $269-275$

VERMEIRSCH, H, SIMOENS, P, CORYN, M, VAN DEN BROECK, W 2001: Immunolocalization of progesterone receptors in the canine ovary and their relation to sex steroid hormone concentrations. Reproduction 122: 73-83 
VESANEN, M 1993: Bovine uterine, cervical and ovarian cytosol estrogen and progesterone receptor concentrations in cystic ovarian disease. Acta Vet Scand 34: 35-43

VESANEN, M, ISOMAA, V, ALANKO, M, VIHKO, R 1991: Bovine uterine, cervical and ovarian estrogen and progesterone receptor concentrations. Anim Reprod Sci 26: 61-71 
Plate V

Doležel R. et al.: Follicular Population... pp. 37-43

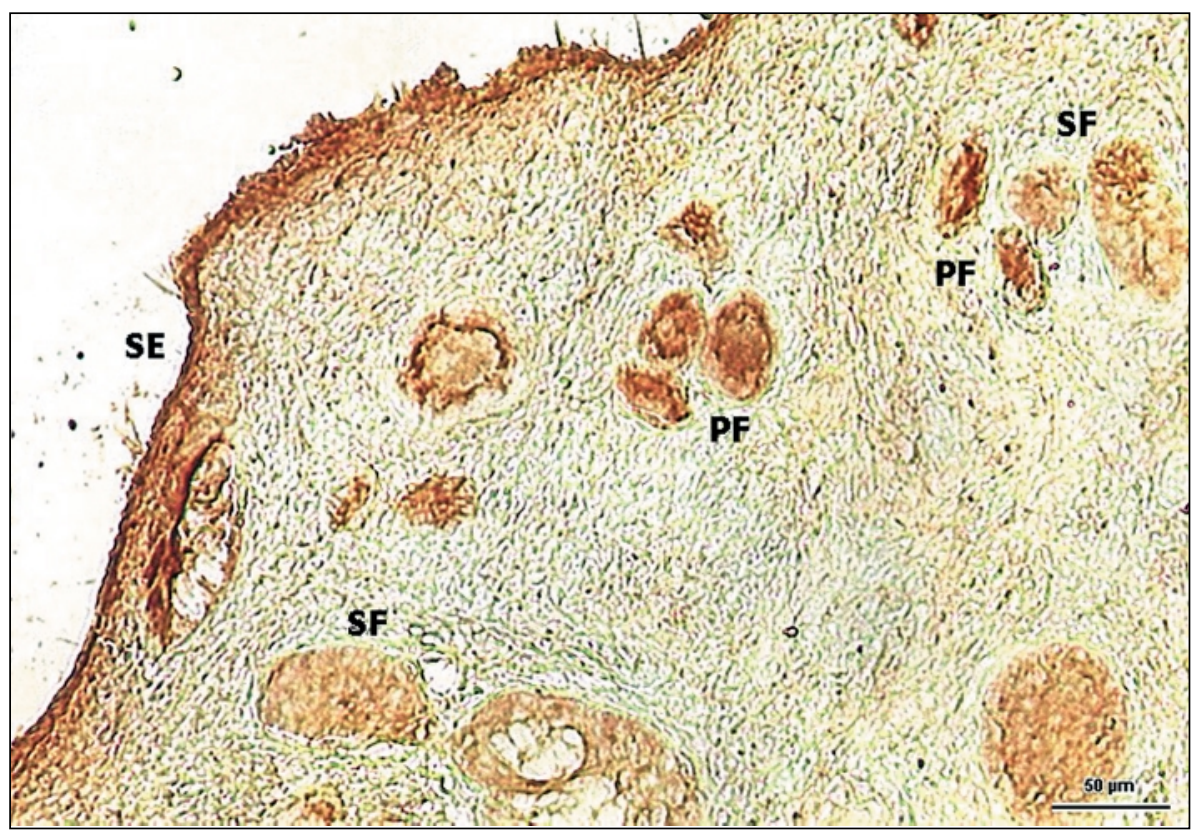

Fig. 3. High intensity of nuclear ER $\alpha$ immunostaining in surface epithelium (SE) as well as in primary follicles (PF) and moderate immunoreactivity in secondary follicles (SF).

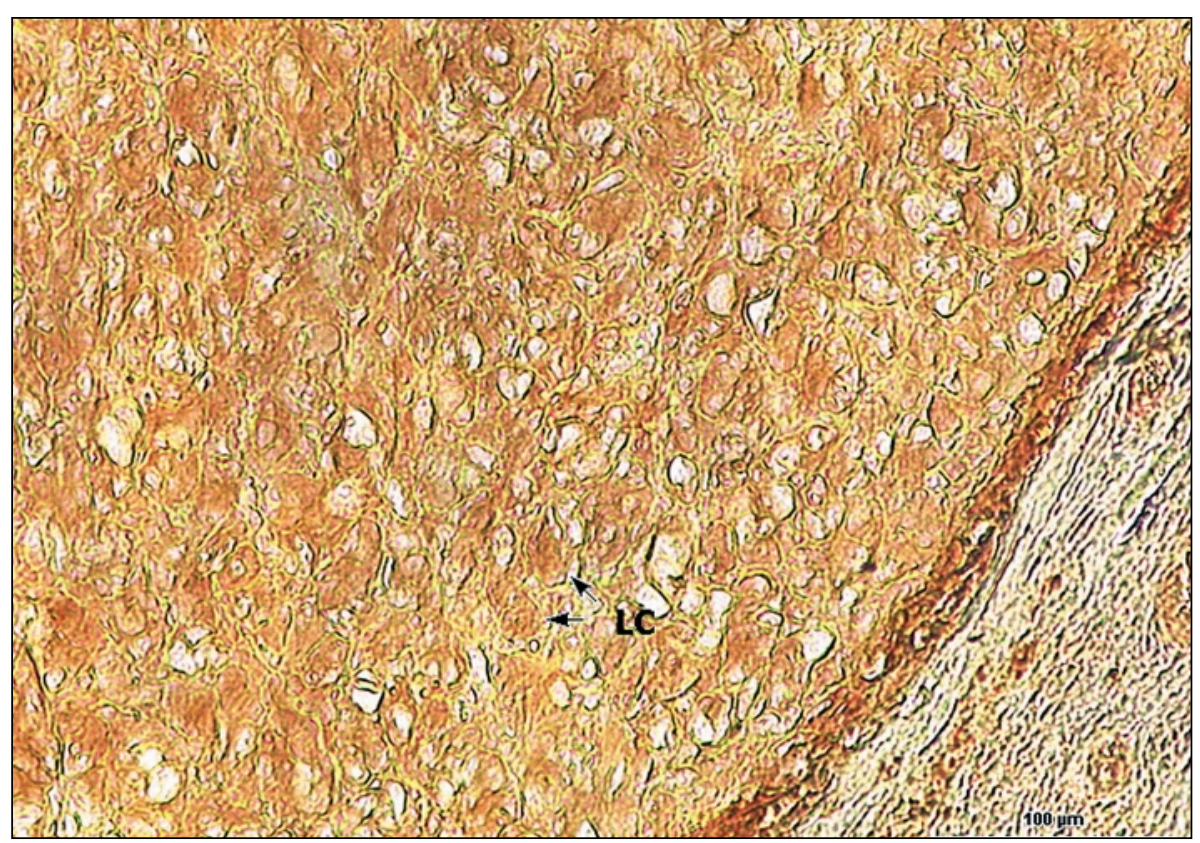

Fig. 4. High intensity of nuclear ER $\alpha$ immunostaining in luteal cells (LC) of corpora lutea. 